\title{
Experience of Investment and Innovative Development of Regional Livestock Production
}

\author{
Ternovykh K.S.* \\ Voronezh State Agrarian University named after Emperor \\ Peter the Great \\ Voronezh, Russia
}

\section{Kucherenko O.I.}

Voronezh State Agrarian University named after Emperor Peter the Great

Voronezh, Russia

e-mail: koi2306@yandex.ru

\author{
Popkova E.V. \\ Voronezh State Agrarian University named after Emperor \\ Peter the Great \\ Voronezh, Russia
}

Korobkov E.V.

Voronezh State Agrarian University named after Emperor Peter the Great

Voronezh, Russia

\begin{abstract}
The aim of the article is to assess the investment and innovation development of regional livestock production. In Voronezh region, livestock breeding is characterized by the intensive growth and dynamic development. During the period under study, milk production in farms of all categories increased by $14.8 \%$, livestock and poultry in live weight - by $57.8 \%$, the amount of eggs - by $5.7 \%$, which is associated with government support, modernization of existing production facilities and construction of new ones. It has been established that the main contribution to the development of the livestock industry is made by integrated agribusiness companies (in dairy cattle breeding: EkoNiva Group of Companies, Molvest JSC; in beef cattle breeding: Zarechnoye Group of Companies; in pig breeding: Agroeko Group of Companies, Verkhnekhav elevator ) whose distinctive feature is production of products with a complete herd turnover, creation of the own feed base, genetic centers, and processing of products.
\end{abstract}

Keywords - livestock production; Voronezh region; agricultural holdings; innovation; livestock systems.

\section{INTRODUCTION}

Livestock farming is one of the main sectors of the agroindustrial complex of Voronezh region. In the structure of the regional gross output, livestock production accounts for $40.7 \%$ [1]. The industry provides the population with essential proteins, animal fats, and macro- and microelements and has a great influence on the development of rural areas, determines quality of life in the rural area. In addition, the efficiency of the processing industry depends on the production of livestock products.

\section{RESULTS AND DISCUSSION}

Recently, livestock production is characterized by the dynamic and intensive development. The statistics shows that for 2014-2018, milk production increased by $14.8 \%$, livestock and poultry - by $57.8 \%$, eggs - by $5.7 \%$ (Table 1 ). At the same time, growth rates for milk and meat were higher than in the Russian Federation as a whole.
TABLE I. DYNAMICS OF THE MAIN TYPES OF LIVESTOCK PRODUCTS IN FARMS OF ALL CATEGORIES [2]

\begin{tabular}{|c|c|c|c|c|c|c|}
\hline \multirow[b]{2}{*}{$\begin{array}{c}\text { Types of livestock } \\
\text { products }\end{array}$} & \multicolumn{3}{|c|}{ Russian Federation } & \multicolumn{3}{|c|}{ Voronezh region } \\
\hline & 2014 & 2018 & $\begin{array}{c}2018, \text { in } \\
\% \text { to } \\
2014\end{array}$ & 2014 & 2018 & $\begin{array}{l}2018 \text { in } \\
\% \text { to } \\
2014\end{array}$ \\
\hline Milk, thousand tons & 29995.2 & 30611.2 & 102.1 & 788.5 & 904.8 & 114.8 \\
\hline $\begin{array}{l}\text { Livestock and poultry } \\
\text { in live weight, total, } \\
\text { thousand tons }\end{array}$ & 12843.2 & 14880.2 & 115.9 & 321.4 & 507.0 & 157.8 \\
\hline including cattle & 2854.9 & 2798.4 & 98.0 & 87.5 & 98.9 & 113.0 \\
\hline pigs & 3812.5 & 4797.1 & 125.8 & 98.0 & 269.8 & 275.3 \\
\hline birds & 5585.1 & 6670.5 & 119.4 & 128.3 & 131.1 & 102.2 \\
\hline sheep & 458.3 & 482.9 & 105.4 & 5.4 & 5.4 & 100.0 \\
\hline Eggs, million pcs. & 41747.3 & 44901.2 & 107.5 & 930.6 & 983.8 & 105.7 \\
\hline
\end{tabular}

An increase in livestock production was due to the modernization of production capacities as part of the project "Development of agricultural sectors providing accelerated import substitution of the main types of agricultural products, raw materials and foodstuffs" of the State program for the development of agriculture and regulation of agricultural markets, raw materials and food [3]. The share of equipment for poultry farming is about $60 \%$, egg production $-20 \%$, poultry meat processing - more than $80 \%$, eggs production $95 \%$. For 2014-2018, 81 new poultry farms were commissioned, 60 poultry farms were modernized, which allowed them to produce 1289.1 thousand tons of poultry.

In pig breeding, a high increase in production is due to the implementation of large investment projects. For 2014-2018, 137 new facilities were commissioned in the Russian Federation, 33 facilities were modernized. In this regard, the additional production of pig meat amounted to 440.8 thousand tons [4].

During this period, 248 new cattle breeding facilities were commissioned and 117 cattle breeding facilities were modernized. Additional production of beef amounted to 64.8 thousand tons [4].

Increasing livestock and poultry production volumes made it possible to increase the physical and economic availability 
of meat and meat products for the population of the region, and reach $82 \mathrm{~kg}$ per person per year in 2018 (Table 2), which is $112 \%$ of the recommended consumption rate.

TABLE II. CONSUMPTION OF MAIN TYPES OF LIVESTOCK PRODUCTS PER CAPITA PER YEAR, KG

\begin{tabular}{|c|c|c|c|c|}
\hline \multirow{2}{*}{ Parameters } & \multicolumn{2}{|c|}{ Russian Federation } & \multicolumn{2}{|c|}{ Voronezh region } \\
\hline & 2014 & 2018 & 2014 & 2018 \\
\hline Milk & 239 & 230 & 270 & 271 \\
\hline Meat & 68 & 69 & 77 & 82 \\
\hline Eggs, pcs. & 267 & 279 & 338 & 339 \\
\hline
\end{tabular}

In 2018, in Russia, egg production per capita was $7.3 \%$ higher than the rational consumption rate $(260 \mathrm{pcs}$.). At the same time, in Voronezh region, the consumption rate exceeds the national average by $21.5 \%$, and the rational norm by $30.4 \%$.

In the structure of livestock production of Voronezh region, agricultural organizations play a leading role [5], whose share is constantly growing (Table 3). During the study period, the share of a large sector of the economy in milk production increased from 56 to $71.8 \%$, the share of livestock and poultry products increased from 68.5 to $83.1 \%$.

TABLE III. THE PROPORTION OF AGRICULTURAL ENTERPRISES IN THE TOTAL VOLUME OF LIVESTOCK PRODUCTS IN VORONEZH REGION, \%

\begin{tabular}{|l|l|l|}
\hline \multicolumn{1}{|c|}{ Types of livestock products } & \multicolumn{1}{c|}{$\mathbf{2 0 1 4}$} & \multicolumn{1}{c|}{$\mathbf{2 0 1 8}$} \\
\hline Milk & 56.0 & 71.8 \\
\hline Livestock and poultry in live weight, total & 68.5 & 83.1 \\
\hline including cattle & 32.6 & 52.0 \\
\hline Pigs & 35.1 & 95.9 \\
\hline birds & 83.5 & 84.7 \\
\hline Sheep & 3.7 & 2.4 \\
\hline Eggs & 63.6 & 65.1 \\
\hline
\end{tabular}

It should be noted that the main contribution to the development of the livestock industry is made by integrated agricultural companies (in dairy cattle breeding: EkoNiva Group of Companies, Molvest JSC; in beef cattle breeding: Zarechnoye Group of Companies; in pig breeding: Agroeko Group of Companies, Verkhnekhavsky elevator). The features of the enterprises are as follows: production with a complete herd turnover, own fodder base, organization of genetic centers, processing of products, bringing the final product to the consumer through own logistics networks.

The studies revealed that the largest integrated milk production unit is EkoNiva Group of Companies, which operates in seven districts: Liskinsky, Kamensky, Bobrovsky, Kashirsky, Anninsky, Buturlinovsky and Talovsky [6].

Up to 1003 tons of milk are produced daily. The total number of cattle is 71,500 heads, including 39,800 heads of feed cows. Of the 30 livestock divisions, $50 \%$ ones are modern dairy facilities using loose housing technologies. All the farms were reconstructed and modernized in accordance with advanced livestock technologies. Europarallel milking machines produced by WestfaliaSurge company are used. All milking parlors are equipped with cooling equipment.

Herd management is carried out using the Dairy Comp program, which allows you to organize the whole range of zootechnical and veterinary activities and analyze and plan the production process. Each cow is equipped with a special chip. During milking, all information enters the computer room, where it is read and processed. The body temperature, pregnancy, milk yield, and milk quality are controlled, which contributes to the preparation of the feeding diet.

The tribal work is organized on the basis of the SELEX program. Information about the readiness of a particular cow for artificial insemination is transmitted to computers through the electronic control system. The animal is immediately isolated from the herd and automatically enters a special machine through separate gates.

The SELEX system contributes to the accumulation of information for each animal, on the basis of which the animal is scored, the genetic potential is analyzed, etc. EkoNiva livestock enterprises are engaged in breeding Simmental, brown Schwitz, Holstein black-and-white, motley suit, redmotley, and Hereford breeds.

Organization of complete animal feeding is crucial. Normalized and balanced diets for animals are developed taking into account their productivity and physiological state. The following components are included in the diet of highly productive dairy cows: corn silage $-23.16 \mathrm{~kg}$, granulated beet pulp $-1.72 \mathrm{~kg}$, alfalfa haylage $-8.52 \mathrm{~kg}$, barley straw $2.27 \mathrm{~kg}$. Concentrate: palm palm fat $-0.3 \mathrm{~kg}$, corn $-5.04 \mathrm{~kg}$, soybean meal $-2.7 \mathrm{~kg}$, rapeseed meal $-2.11 \mathrm{~kg}$, wheat $1.8 \mathrm{~kg}$, chalk $-0.04 \mathrm{~kg}$ [7].

Much attention is paid to the use of advanced technologies for the preparation and storage of feed. New methods of harvesting bulky feed (silage, haylage) in polymer sleeves using a system of preserving drugs are used. Hay is stored in closed silos.

EkoNivaAgro LLC implements a project for the organization of industrial feed production, which involves feeding feed in the form of monocorm, consisting of several ingredients - haylage, silage, concentrates and molasses. Such food is prepared at the complex in a special grinder-mixer [8].

A feature of the EkoNiva Group of Companies is milk processing factories that produce high-quality dairy products EKONIVA, Academy of Dairy Sciences and Big Change. In addition, in Voronezh, Kaluga and Novosibirsk regions, the agro-tourism project "Academy of Dairy Sciences" is being implemented. Its goal is to popularize milk, a healthy lifestyle and rural professions.

The structure of JSC Molvest includes 10 dairy farms, four of which are located in Voronezh region: SHP "Milk of Chernozemye", SHP "Novomarkovskoye", LLC "Nikolaev Farms", LLC "Mamonovsky Farms" [9]. At present, Molvest JSC is the largest Russian producer without the participation of foreign capital. Molvest LLC processes more than 500,000 tons of milk per year and produces about 250 dairy products of 8 brands. The main brand of dairy products is Vkusnoteevo.

The "Milk of the Black Earth Region" company is the largest farm in Europe. It produces 107,000 liters of milk daily. The number of cows is 5500. For milking, Karusel milking parlors are used. They are the fastest, most convenient 
and efficient way of milking on farms with over 1000 cows. It is based on a moving platform that moves the cow to the milking operator. On one carousel, 60 cows are simultaneously placed, the full rotation cycle is 12 minutes, of which milking is 8 minutes. The process is fully automated. Milking is carried out by three machine milking operators: they wipe the udder from the dirt, handle it with special solution, attach the milking cups to each cow. When less than $200 \mathrm{~g}$ of milk remains in the udder, the milking machine automatically shuts off and is removed from the udder. The control panel located in the milking parlor allows the operator to monitor the main indications: the beginning, end of the process, speed and movement of cows in the milking parlor, etc. All milk enters a tank - a container where it is cooled. When the milking process is over, the milking machine gradually falls into its place automatically, and the cow leaves the platform

The dairy farm in the agricultural holding Novomarkovskoye is the most high-tech farm. It has implemented the roboticized milking process. The Center for Breeding and Genetics with a section for 9600 calves has the status of a pedigree reproducer of breeds Jersey, Montbeliard and Belgian Blue breeds. The own feed mill allows it to produce high-quality animal feed, taking into account age and sex characteristics of cattle.

In the meat cluster of Voronezh region, there is an innovation-oriented beef production agroholding Zarechnoye. It consists of enterprises with a full cycle of beef production. They will include genetics, animal husbandry, fodder production and meat processing. This approach allows the company to optimize all costs and minimize risks. Black Angus cattle are bred.

Cattle fattening is carried out at open specialized sites (feedlot). On farms, animals are raised to a certain age and weight, and transferred to a special open area, where they are fed with grain. Grain fattening gives meat juiciness, marbling and softness. The average daily gain is up to $1.5 \mathrm{~kg}$. The feedlot is designed in such a way that the animals are always kept clean and completely free from any stress. At the same time, the influence of the feedlot on the environment is minimized.

Due to the simplicity of construction and a high level of mechanization, feedlots reduce the cost of beef production and make it competitive.

The total area of facilities is about 100 hectares, and onetime loading is 24,000 heads. All works are performed using the best equipment by leading manufacturers [10].

The studies have established that pig farming is developing intensively in Voronezh region. For 2014-2018, pork production increased 2.7 times. It was possible to achieve such accelerated growth rates due to the construction of new industrial-type facilities using modern innovative technologies, and automated equipment by leading foreign and domestic companies.

The innovative development of pig farming has changed the industry and organization of the production process. Pork production is organized in three areas: a reproducing area (growing repair pigs and preparing them for insemination, keeping pregnant and lactating mothers), a growing area (raising young animals after weaning) and a feeding area.For each technological group of pigs, there are separate sections, boxes or buildings which makes it possible to use the means of mechanization and rationally organize the work of maintenance personnel. After the end of a production cycle, the room is vacated, cleaned and disinfected. Each box contains pigs that are close in age and, and of the same sex [11]. Modern pig farms operate in a closed mode, equipped with disinfection barriers for cars and sanitary inspection for the personnel, which minimizes the spread of various diseases.

Particular attention is paid to the maintenance of lactating animals. Farrowing zones are equipped with special machines fixing lactating animals, which eliminates the crushing of piglets. The floor is slotted, made of plastic, which prevents injuries to piglets. In order to exclude the incidence, heated panels, electric mats, and infrared lamps are mandatory [11]

The microclimate is regulated by automatic systems that provide optimal temperatures and air exchange. For example, in summer, the irrigation system is used to lower the temperature, which involves spraying finely divided fractions of cold water.

Feeding is carried out using automated equipment (WEDA, Big Dutchman, etc.), which allows you to feed animals at a strictly determined time or when the feeders are emptied. Each feed hopper is equipped with load cells that take into account feed consumption and evaluate the feed formulation efficiency and animal genetic potential. In addition, modern feeding systems are able to record changes in the animal weight per unit time and the average daily gain in an automatic mode. Pigs that have reached the desired weight are fed with cheaper feed. If the animal is behind in weight, it is sent for treatment [12].

An analysis of management practices shows that modern pig-breeding enterprises have sufficient capacities for the production of animal feed, which significantly reduce production costs. The high-tech feed mill GK Agroeko produces 290 thousand tons of feed per year [13]. The company produces feed for each group of pigs, taking into account the technological cycles, breed and productivity. In 2019, the agricultural holding built a new feed mill in t Pavlov district. Productivity of the plant is 20 tons/hour of compound feed for adult animals and 5 tons/hour of starter compound feeds for piglets. The project provides for a subsequent increase in capacity of up to $40 \mathrm{t} / \mathrm{h}$ [14].

An important aspect of the intensive development of pig farming is reproduction of the herd and improvement of breeding and productive qualities of animals. Therefore, many agricultural holdings create their own pivot-hybrid centers. For example, the Verkhnekhav agricultural holding incorporates SGTs LLC, which was awarded the status of a breeding and genetic center in 2011. The company is engaged in breeding large white pigs, landrace, duroc (French genetics) and hybrid pigs for industrial reproducers. It sells seed material.

The genetic center of the Agroeko Group of Companies reproduces pure-bred animals of Canadian genetics Genesus, 
which have the following advantages: growth rate, good health, and multiple births. Pigs reach the slaughter weight in a shorter period due to the high average daily growth (over 1 $\mathrm{kg}$ ), which allows the more efficient use of production facilities. Genesus animals can consume cheaper feeds that contain lower levels of lysine and protein when converted to 2.7 feed units. Thus, a commodity pig weighing $127 \mathrm{~kg}$ can be raised for 168-170 days [15].

\section{CONCLUSION}

An analysis of the investment and innovative development of livestock in Voronezh region allowed us to draw the following conclusions:

First, livestock production is one of the main sectors of the agro-industrial complex of Voronezh region. In the structure of the regional gross output, livestock production accounts for $40.7 \%$.

Second, livestock production is characterized by dynamic and intensive development. For 2014-2018, milk production increased by $14.8 \%$, livestock and poultry production - by $57.8 \%$, eggs production - by $5.7 \%$, due to the government support, modernization of existing facilities and construction of new ones, as well as technologically related industries feed production, storage, and processing.

Third, agricultural organizations play a leading role in the structure of production; in the total volume, their share is growing. During the period under study, the share of milk production increased from 56 to $71.8 \%$, livestock and poultry production - from 68.5 to $83.1 \%$

Fourth, the main contribution to the development of the livestock industry is made by integrated agribusiness companies (in dairy cattle breeding: EkoNiva Group of Companies, Molvest JSC; in cattle breeding: Zarechnoye Group of Companies; in pig breeding: Agroeko Group of Companies, Verkhnekhavsky elevator) whose specifics is production of products with a complete turnover, creation of own feed bases, genetic centers, processing of products produced.

Fifth, innovative technologies and automated equipment of leading foreign and domestic companies have been used at modern breeding farms, which allows them to produce highquality and competitive products.

\section{References}

[1] Voronezh region in numbers. Voronezh: Stat. Sat/Voronezhstat, 2019, $84 \mathrm{p}$.

[2] Bull. on the state of agricult. Retrieved from: https://www.gks.ru/ compendium/document/13277.

[3] National Union of Poultry Breeders. Retrieved from: https://poultryunion.org/

[4] "On the progress and results of the implementation of the 2018 State Program for Development of Agriculture and Regulation of Agricultural Products, Raw Materials and Food Markets for 2013-2020", National report. Moscow, 2019, 248 p. Retrieved from: http://mcx.ru/upload/ iblock/61d/61d430039b8863186a4fbb1f60fab1c6.pdf.

[5] E.V. Salnikova, E.A. Popova, E.V. Zakshevskaya, "Regional meat market: a specific structure and development priorities", IOP Conf. Ser. Earth and Environmental Sci., p. 012022, 2019.

[6] EkoNivaAgro. Retrieved from: https://ekoniva-apk.ru/ekonivaagro

[7] A.V. Aristov, L.A. Esaulova, S.N. Semenov, A.M. Skogoreva, L.A. Matyushevsky, "A way to increase the implementation of the bioresource potential of animals and birds", IOP Conf. Ser. Earth and Environmental Sci., p. 012053, 2020. Voronezh State Agrar. Univer. named after Emperor Peter the Great.

[8] K.S. Ternov, L.V. Dankova, N.A. Zolotareva, Yu.A. Pimenov, "Features of the organization of milk production in integrated agro-industrial formations", Bull. of the Voronezh State Agrar. Univer., vol. 3, no. 58, pp. 148-158, 2018.

[9] Molvest. Retrieved from: https://www.molvest.ru/

[10] I. Glazkova, "Producer of the premium segment of the Russian beef market", Meat technol., vol. 10, no. 178, 26-29, 2017.

[11] O.I. Kucherenko, E.V. Popkova, "Innovation as a factor in the effective development of pig farming", Bull. of Voronezh State Agrari. Univer., vol. 4, no. 39, pp. 252-255, 2013.

[12] A modern approach to breeding pigs from Agroeko Group of Companies. Retrieved from: http://agrarnik.ru/news/sovremennyjpodhod-v-vyrawivanii-svinej-ot-gk-agrojeko 4849 /

[13] S.N. Konovalova, V.V. Trubnikova, "The main directions of innovative development of the agro-industrial complex of Voronezh and Kursk regions", pp. 60-63, 2016 [Innovative development of the Russian economy, IX Int. sci.-pract. Conf.]. Moscow: Russ. Univer. of Econ. G.V. Plekhanova.

[14] Agroeko. Retrieved from: http://agroeco.ru/Pages/index.asp

[15] Modern genetics is one of the main competitive advantages. Retrieved from: https://www.agroinvestor.ru/business-pages/29627-stremlenie-kgeneticheskomu-progressu/

[16] E.I. Goroshko, Integrative model of free associative experiment Moscow: Institute of Linguistics of the Russian Academy of Sciences, $2001,320 \mathrm{p}$ 